\title{
The Relationship between Parents' Attention and Self Concept with Learning Achievements in Tenth Grade Students of SMA Negeri 3 Pematangsiantar
}

\author{
Susy Alestriani Sibagariang ${ }^{1}$, Tambos August Sianturi ${ }^{2}$, Sahat Sitompul $^{3}$
}

The Economics Study Program of Universitas HKBP Nommensen Pematangsiantar, Indonesia, The Mechanical Engineering Study Program of Universitas HKBP Nommensen Pematangsiantar, Indonesia

Received: 10 Oct 2020; Received in revised form: 14 Nov 2020; Accepted: 15 Nov 2020; Available online: 18 Nov 2020 (C2020 The Author(s). Published by Infogain Publication. This is an open access article under the CC BY license (https://creativecommons.org/licenses/by/4.0/).

\begin{abstract}
This study aims to determine the relationship between parental attention and self-concept with student achievement in tentg grade of SMA Negeri 3 Pematangsiantar in academic year 2019/2020. This research is descriptive quantitative with the instrument used is a questionnaire that has been tested for the validity of the instrument and documentation. Based on the results of data analysis, it can be concluded that the correlation coefficient between the variables of parental attention and learning achievement is $0.57(57 \%)$ and after being compared with $r$ table $0.164(\alpha=0.05)$, the rest of the level of relationship can be influenced by other variables, and the magnitude The correlation between self-concept variables and learning achievement is $0.50(50 \%)$ and after being compared with $r$ table $0.164(\alpha=0.05)$, the rest of the level of the relationship can be influenced by other variables, and the magnitude of the correlation between parental attention and self-concept variables with learning achievement of 0.78 (78\%) and compared with $r$ table $0.164(\alpha=0.05)$. This means that it is significant, so the hypothesis $(\mathrm{Ha})$ is accepted and it can be concluded that the greater the parental attention and self-concept, the higher the learning achievement.
\end{abstract}

Keywords—Parents' Attention, Self-Concept and Learning Achievement.

\section{INTRODUCTION}

A parent's role is especially needed when it comes to watching a child's progress in learning. This is still the case within the family circle being left to the teacher in the schools. A lack of parent attention also result in a child's personality, where she/he feels free or out of control and that the learning process is interrupted.

The observation of the writer as a lecturer who also has to be responsible for the phenomena that occur today such as the phenomenon of current parental attention, including: It is evident from the many bustle of parents in their daily work and activities, It is evident from today's parents that they are more interested in their own activities when it comes to controlling a child's learning process, There is still a lack of parental interest in child studying which is evident from the child's inadequate learning, While parents still lack concern for their child's study needs, it is evident that many of the needs for children to go to school are neglected. Parents must strive to guide their children in learning, to oversee the child's learning process, to motivate them to learn and to meet their child's learning needs.

Likewise with self-concept, worth in children results from lack of the opportunity to talk with others, it is difficult to admit that they are wrong, are unable to express their feelings in a normal way, tend to be unnoticed and unpopular by others, so that the child acts on others as an enemy, thereby creating warmth, a closeness of friendship.

Another problem researchers have discovered is the concept of self-worth in school work tends to lack 
confidence in their abilities. Students still avoid interacting with their friends when they have difficulty studying such as enganging in discussion with friends and students tend to be less honest during exams.

\section{REVIEW OF LITERATURE}

\section{Parents Attention}

The term of attention is an activity of the soul directed something,both inside and otutside itself. Furthermore, according to Abu Ahmadi and widodo Supriyono (2013: 41), that attention is the concentration or activity of the soul o observation, understanding in leaving the others aside. Meanwhile, according to Slameto (2010: $105)$ is a person's activity in relation to the stimulus selection coming from her/his ward. From several definitions by experts that have been described researchers can conclude that attention is in the individual's concentrations on an object that is both inside and outside the individual.

The term parent is the most important figure in the form of children's character besides teachers at school. Furthermore, Indonesian Dictionary (2012: 987), parents are fathers, biological mothers (people who are considered old, people who are respected and respected). Furthermore, according to Simanjuntak (2005: 7) states that parents are a mother and a father, the one closest to a child. the writer may conclude that understanding of the parent is an important role in the development of a child's identity. From both the terminology terms,researchers backed up the terms,so that a parent's awareness of caring for the child,both in guiding children, educating, and meeting their children's needs.

\section{Kinds of Parental Attention}

According to H. Abu Ahmadi (2018: 144) mentions a variety of attention, including the following:

1. Spontaneous and deliberate attention deliberate attention generated by the will on account of a specific purpose.

2. Statistical attention is constant attention to something. Dynamic attention is fluid mindfulness,easily shifting from one object to another.

3. Concentrative attention (focused attention), namely attention that is only directed at one particular object (problem). Distributive attention (divided attention).
4. Narrow attention is focused on a limited object. Broad attention is that people who have great attention are more likely to be drawn to the surrounding scenes.

5. Fictitious (fixed attention) attention, that is easily focused on a subject or that it can linger on the object. The fluactive (corrugated) attention can be observed at one time or another,but most are not careful.

Furthermore, according to Janwar Tambunan (2015: 149) attention can be distinguished, as follows:

1. Intentional attention.

2. Spontaneous attention.

3. Intensive attention.

4. Centered attention.

5. Gushing/various attention.

Furthermore, according to Abu Ahmadi \& Widodo Supriyono (2013: 41) mentioning the types of attention,which is:

1. Senses attention

2. Spiritual concern.

3. Deliberate attention.

4. Involuntary attention.

From all kinds of attention it can be conclude that a parent's attention to a child can be seen by his or her parental upbringing and way of dealing with their child.

\section{Factors that Influence Parental Attention}

In focusing attention on an object, there are certainly may factors that influence attention.

According to $\mathrm{H}$. Abu Ahmadi mentions a number of factors affecting attention:

1. Disposition

There are certain traits associated with the object being reacted, so a little or a lot of attention will arise to that particular object.

2. Practices and habits

Even though it is felt that there is no natural talent for nature,but because of practice it can readily give the attention given to the field.

3. Needs

The need for something could be attracting attention to the object.

4. Obligation

The obligation contains responsibilities that must be fulfilled by the person concerned.

5. Physical state 
Physical health or not, whether the body is fresh or not, has a profound effect on our attention to something object.

6. Physicological climate

Mental states, feelings, fantasies, thoughts and so on greatly influence our attention, may be helpful, and vice versa can also be inhibiting.

7. Surrounding atmosphere

The existence of various stimulants around us such as noise, commotion, chaos, temperature, socioeconomic, beauty and so on can affect our attention.

8. The decomposition of the stimulant itself How strong the stimulant is concerned with the object of attention greatly affects our attention.

Furthermore, according to Wina Sanjaya (2008: 268) the factors that can affect parental attention are:

1. The physical condition of each individual

2. Motivation of each individual.

3. Individual needs.

4. Clear goals.

Furthermore, according to Sumadi Suryabrata (2017: 14), attention can be distinguished, including:

1. On the basis of the intensity

Much or less awareness that accompanies an activity or mental experience

2. On the basis of how it arose

Spontaneous attention (involuntary attention) and reflexive attention (intentional attention).

3. On the basis of the object which is subject to attention

Distributive attention and concentrated attention.

\section{The Nature of the Concept}

The self-cocept terms are about "who I am" and "how I feel about myself". But people don't have a unifiedconceptof self. They think of themselves in some way in various situations. In the book M. Nur Ghufron \& Rini Risnawati (2018: 13-14) according to Burn, defines self-concept as an impression of oneself, and an opinion of oneself in the eyes of others, and an opinion of what is being achieved.According to Slameto (2010: 182) states that self-concept is a belief about one's own state that is relatively difficult to change. Thus,from some of the definitions presente by experts it can be deduced that a concept of self is what a person feels and what one thinks about her/himself.

\section{The Essence of Learning Achievement}

The term learning achievement is the maximum effort one achieves after learning efforts. According to R.
Raudlatun Nikmah (2018: 81) learning achievement is the achievement of students as a result of completing certain tasks or activities at school. In the book Euis and Donni (2018: 155) according to Purwanto, learning achievement is a change in behavior that result from following the teaching process that is for purpose of education.So, from several definitions put forward by experts, it can be concluded that learning achievement is the result obtained by students in carrying out the tasks they are doing.

\section{Research Methodology}

This type of research used is descriptive quantitative. According to Sugiyono (2012: 14) quantitative research methods can be interpreted as research methods based on the philosophy of positivism, used to research on certain populations or samples, sampling techniques are generally carried out randomly, data collection uses research instruments, data analysis is quantitative / statistics with the aim of testing the hypothesis that has been set ". This research was conducted by SMA Negeri 3 Pematangsiantar.

\section{RESULT AND DISCUSSION}

The writer acknowledges that this study is imperfect for both writing and content because it still has such infirmities as the following:

1. The questionnaire / instrument used was insufficient as a data collection tool because it was limited in terms of the number of questions asked to students.

2. The extent of the educational subject being the sample has not been able to fully represent the research compilation.

3. The data obtained from field research are purely converted into numerical form so that there is a possibility of miscalculation.

Research conducted by the writer "The Relationship of Parents' Attention and Self-Concept on Learning Achievement" with total sample are 100 people. Data collection tools were questionnaires and achievement tests. The results showed that the variable parental attention was more influential (0.57) than the self-concept (0.50). Many factors influence low levels of learning,some of which are parental attention and self-concept.

\section{A. Discussion}

\section{Parents' Attention}

As for results obtained in each statement item that has been given to respondents, as follows: 
1. The results of the instrument from 100 samples in the first indicator, 57 answered strongly agree, 30 answered agree, 4 disagreed, 9 answered strongly disagree; 2) The second statement 38 people answered strongly agree, 54 answered agreed, 6 disagreed, 2 answered strongly disagreed; 3) The third statement 49 people answered strongly agree, 32 answered agree, 9 disagreed, 10 answered strongly disagreed; 4) For the fourth statement, 42 people answered strongly agree, 38 answered agreed, 9 disagreed, 11 answered strongly disagreed; 5) The fifth statement 48 people answered strongly agree, 37 answered agreed, 10 disagreed, 5 answered strongly disagreed; 6) The sixth statement 34 people answered strongly agree, 50 answered agreed, 12 disagreed, 4 answered strongly disagreed; 7) The seventh statement 26 people answered strongly agree, 45 answered agreed, 20 disagreed, 9 answered strongly disagreed; 8) The eighth statement 26 people answered strongly agree, 33 answered agreed, 26 disagreed, 15 answered strongly disagreed; 9) The ninth statement 27 people answered strongly agree, 38 answered agreed, 26 disagreed, 9 answered strongly disagreed; 10) The tenth statement of 57 people answered strongly agree, 28 answered agreed, 8 disagreed, 7 answered strongly disagreed; 11) The eleventh statement 35 people answered strongly agree, 50 answered agreed, 12 disagreed, 3 answered strongly disagree; 12) The 12th statement of 53 people answered strongly agree, 34 answered agree, 9 disagreed, 4 answered strongly disagreed.

\section{Self-Concept}

The results obtained in each statement item that have been given to respondents are as follows:

The results of the instrument from 100 samples in the first indicator, 54 answered strongly agree, 21 answered agree, 10 disagreed, 15 answered strongly disagree; 2) The second statement 52 people answered strongly agree, 36 answered agreed, 10 disagreed, 2 answered strongly disagreed; 3) The third statement 46 people answered strongly agree, 43 answered agreed, 8 disagreed, 3 answered strongly disagreed; 4) The fourth statement 46 people answered strongly agree, 35 answered agreed, 12 disagreed, 7 answered strongly disagreed; 5) The fifth statement 47 people answered strongly agree, 37 answered agreed, 10 disagreed, 6 answered strongly disagreed; 6) The sixth statement 40 people answered strongly agree, 29 answered agreed, 22 disagreed, 9 answered strongly disagreed; 7) The seventh statement 48 people answered strongly agree, 39 answered agreed, 7 disagreed, 6 answered strongly disagreed; 8) The eighth statement 45 people answered strongly agree, 26 answered agreed, 24 disagreed, 5 answered strongly disagreed; 9) The ninth statement 47 people answered strongly agree, 33 answered agreed, 6 disagreed, 4 answered strongly disagreed; 10) The tenth statement 50 people answered strongly agree, 37 answered agreed, 7 disagreed, 6 answered strongly disagreed; 11) The eleventh statement 43 people answered strongly agree, 33 answered agreed, 10 disagreed, 4 answered strongly disagreed; 12) The 12th statement 49 people answered strongly agree, 39 answered agree, 8 disagreed, 4 answered strongly disagreed.

Based on the results of the simple correlation analysis that has been done, there is a link between the variables of parental attention,self awareness, and the performance of studying at SMA Negeri 3 Pematangsiantar. And the significant value of of 0.000 $<0.005$. That means the value is significant because it's less than 0.005. That means, there is a correlation to parental attention, self-concept, and student achievement.

\section{CONCLUSION}

Based on the data processing results, the description of hypothetical testing is following:

1. There is a positive and significant relationship between parental attention and student achievement in tenth grade of SMA Negeri 3 Pematangsiantar, namely 0.57 or $57 \%$, the current relationship rate of 0.57 or 57 percent,which is affected the rest of the variables. So this research shows that the higher the parents' attention learning achievement.

2. There is a positive and significant relationship between self-concept and student achievement in tenth grade of SMA Negeri 3 Pematangsiantar namely 0.50 or $50 \%$, the level of the relationship is moderate, the rest can be influenced by other variables. So this study shows that the higher selfconcept and the higher learning achievement

3. There is a positive and significant relationship between parental attention and self-concept with student in tenth grade of SMA Negeri 3 Pematangsiantar namely 0.78 or $78 \%$, the remaining strong relationship level can be influenced by other variables. So this study shows that the higher the attention of parents and selfconcept and the higher the learning achievement. 


\section{REFERENCES}

[1] Ahmadi Abu, 2018. Psikologi Umum. Jakarta: Rineka Cipta.

[2] Arikunto Suharsimi, 2014. Prosedur Penelitian. Jakarta: Rineka Cipta.

[3] Ghufron Nur, 2018. Teori-teori Psikologi. Jogjakarta: ARRuzz Media.

[4] Hamdani, 2017. Strategi Belajar Mengajar. Bandung: CV Pustaka Setia.

[5] Karwati Euis, 2018. Manajemen Kelas. Bandung: Alfabeta.

[6] Muhadi Yunanto, 2016. Cara Kita Mendidik Anak. Yogyakarta: Diva Press.

[7] Nikmah Raudlatun, 2018. Bimbingan Konseling Berbasis Evaluasi dan Supervisi. Yogyakarta: Araska.

[8] Slameto, 2010. Belajar Dan Faktor-Faktor Yang Mempengaruhi. Jakarta: Rineka Cipta.

[9] Sugiono, 2012. Metode Penelitian Pendidikan. Bandung: Alfabeta.

[10] Wibowo, 2016. Perilaku Dalam Organisasi. Jakarta: PT. Rajagrafindo Persada.

[11] Widodo, 2013. Psikologi Belajar. Jakarta: Rineka Cipta.

[12] Ningsih Rita dan Nurrahmah Arafatin, 2016. Hubungan Kemandirian Belajar dan Perhatian Orang Tua terhadap Prestasi Belajar Matematika. Jurnal Formatif 6 (1) : 7384, ISSN : 2008-351X.

[13] Nanda Aris, Yunus Muhammad dan Hayati Erna, 2016. Hubungan Antara Perhatian Orang Tua dengan Prestasi Belajar PKn Pada Siswa MTsN Tungkob. Jurnal Ilmiah Mahasiswa Pendidikan Kewarganegaraan Unsyiah Volume 1, Nomor 1:13-22. 